\title{
Functionally redundant interactions between U2 and U6 spliceosomal snRNAs
}

\author{
Deborah J. Field and James D. Friesen ${ }^{1}$ \\ Department of Molecular and Medical Genetics, University of Toronto, and Department of Genetics, Hospital for Sick \\ Children, Toronto, Ontario, Canada
}

\begin{abstract}
Base-pairing between U2 and U6 snRNAs to form intermolecular helix II has been demonstrated previously as a requirement for pre-mRNA splicing in mammalian cells. In contrast, deletion and substitution mutation experiments in yeast have indicated that helix II is not essential; instead, other regions of U2 and U6 have been proposed to pair, forming a helix called Ib. To investigate the importance of U2/U6 helices in yeast, we have systematically mutagenized the regions proposed to form helices II and Ib. Allele-specific suppression of certain U6 mutations by complementary substitutions in U2 shows that helix II indeed form in yeast but that it is essential only in the presence of additional mutations that disrupt U2 stem I and the proposed helix Ib. Similarly, the proposed helix Ib is essential only when helix II is disrupted. These observations provide an explanation for apparently conflicting data in yeast and mammalian experimental systems, and identify synergistic or functionally redundant interactions between U2 and U6 snRNAs.
\end{abstract}

[Key Words: Pre-mRNA splicing; Saccharomyces cerevisiae; U2/U6 helices; allele-specific suppression; synthetic lethality]

Received May 15, 1995; revised version accepted December 28, 1995.

Nuclear precursor messenger RNA (pre-mRNA) splicing occurs in a large multisubunit complex called the spliceosome. This complex consists of the pre-mRNA, small nuclear ribonucleoprotein particles (snRNPs) containing U1, U2, U4/U6, and U5 small nuclear RNAs (snRNAs), as well as transiently associated snRNP and spliceosomal proteins (for review, see Guthrie 1991; Moore et al. 1993). During pre-mRNA splicing several changes occur in base-pairing interactions among the snRNAs: For example, U4 dissociates either partially or completely from U6 (Yean and Lin 1991), and U6 associates with U2 to form the active spliceosome (for review, see Weiner 1993; Nilsen 1994). Several base-pairing interactions, called helices Ia, Ib, and II (Fig. $1 \mathrm{~A}, \mathrm{~B}$ ), have been proposed between U2 and U6 snRNAs (Madhani and Guthrie 1992; Weiner 1993). An additional interaction, helix III, has also been described (Sun and Manley 1995). The $5^{\prime}$ region of $\mathrm{U} 2$ is also thought to form an alternative structure, an intramolecular U2 stem-loop I (Keller and Noon 1985), which would be mutually exclusive with $\mathrm{U} 2 / \mathrm{U} 6$ helix Ib and II. Formation of U2/U6 helix II would permit the simultaneous formation of the predicted helices Ia and Ib (Madhani and Guthrie 1992) or, alternatively, an elongated intermolecular Ia as well as the intramolecular U2 (top of stem I) and the intramo-

\footnotetext{
${ }^{1}$ Corresponding author.
}

lecular U6 helix (Fortner et al. 1994; Sun and Manley 1995).

Data from different experimental systems have not yet provided a unified picture of the importance of these U2/U6 interactions. U2/U6 helix II has been demonstrated in both HeLa and trypanosome extracts by crosslinking experiments (Hausner et al. 1990; Watkins and Agabian 1991; Wassarman and Steitz 1992). Comparative sequence analysis suggests that helix II forms in all eukaryotic species for which sequence data are available (Hausner et al. 1990). In keeping with a functional role for helix II, the $5^{\prime}$ region of human U2 is sensitive to mutation; for example, nucleotides 2-6 cannot be substituted by their yeast homologs without abolishing splicing (Wu and Manley 1992). Sensitivity to mutation appears to be dependent on the particular assay used (Datta and Weiner 1991; Wu and Manley 1991; Sun and Manley 1995). Four different point mutations abolish pre-mRNA splicing in a reporter construct containing the SV40 t-antigen intron, three of which have been shown to be suppressible in an allele-specific manner (Wu and Manley 1991). In a $\beta$-globin intron reporter, splicing is abolished in only three of six block substitutions made in this region of $U 2$; for a single 4-nucleotide substitution in $U 2$, splicing is restored only if all four of the corresponding bases of $\mathrm{U} 6$ are changed to be complementary (Datta and Weiner 1991). In vitro, when 20 nucleotides are deleted from the 3' end of human U6, splic- 
ing is reduced to $<10 \%$ of wild-type levels, and both tri-snRNP and spliceosome assembly are decreased to background levels (Wolff and Bindereif 1992). Similarily, point mutations in this same $3^{\prime}$ region of human U6 abolish splicing and severely affect spliceosome assembly (Wolff and Bindereif 1992).

In contrast to the observations with their human counterparts, the regions of $\mathrm{U} 6$ and $\mathrm{U} 2$ proposed to form helix II in Saccharomyces cerevisiae are surprisingly tolerant of substitution and even deletion mutations. For example, deletion of almost all of the U6 nucleotides proposed to form helix II (U6 nucleotides 90-98) resulted in only a slightly cold-sensitive growth phenotype (Madhani et al. 1990). In vitro, an 18-nucleotide deletion from the $3^{\prime}$ end of $U 6$ results in diminished splicing and accumulation of free lariat (Fabrizio et al. 1989). In vivo yeast U2 can tolerate a deletion from nucleotides 4-13 (Madhani and Guthrie 1994a), as well as an exchange of the first 106 nucleotides of human U2 for the first 120 nucleotides of yeast $\mathrm{U} 2$; the resulting human-yeast chimera complements a $\mathrm{U} 2$ deletion in $S$. cerevisiae (Shuster and Guthrie 1990; Miraglia et al. 1991).

In an effort to understand these paradoxical differences in the apparent importance of helix II, we systematically mutagenized the $3^{\prime}$ region of $\mathrm{U} 6$ and the $5^{\prime}$ region of $\mathrm{U} 2$ in S. cerevisiae and evaluated the effects on growth and mRNA splicing. We found that $\mathrm{U} 2$ is tolerant of large substitutions in this region, whereas U6 is very sensitive. We show that although helix II is not essential, its presence is critical only when otherwise silent mutations are present in the region of U2 proposed to form helix Ib. We also find that this region of U2 proposed to form helix Ib is not essential unless helix II is disrupted. The identification of these synthetic lethal interactions suggests that U2/U6 helix II, U2/U6 helix Ib, and possibly U2 stem I, are functionally redundant or synergistic structures involved in pre-mRNA splicing.

\section{Results}

To evaluate the phenotypes of mutations in $\mathrm{U} 2$ and $\mathrm{U} 6$ snRNAs, a strain was constructed in which the chromosomal copies of the U2 and U6 genes were deleted and replaced by $H I S 3$ or $A D E 2$, respectively. Both deletions can be complemented by a single URA3 centromeric plasmid (pRS316-U2/U6), containing one copy each of the wild-type U2 and U6 genes; this yeast strain is designated YDF426 (Fig. 1C). Alternatively, U2 and U6 can be supplied by individual plasmids: U2 on a TRP1 centromeric plasmid (pU2), and U6 on a LEU2 centromeric plasmid (pU6). The strain with these two plasmids shows no growth or splicing defects (Figs. 2-6, below; data not shown). Yeast strains were cotransformed with plasmids containing mutations in $\mathrm{U} 2$ and/or $\mathrm{U} 6$, and in addition, where appropriate, with a plasmid encoding the wild-type allele of the other snRNA (pU2 or pU6) into YDF426. Transformants were spread on solid-selective medium and were incubated at $30^{\circ} \mathrm{C}$. They were then patched on agar containing 5-fluoro-orotic acid (5-FOA), which allows growth only of cells that have lost the
URA3-marked plasmid containing the wild-type $\mathrm{U} 2$ and U6 genes, and incubated at $23^{\circ} \mathrm{C}, 30^{\circ} \mathrm{C}$, and $33^{\circ} \mathrm{C}$.

\section{U2/U6 helix II is not essential}

The role of U2/U6 helix II was investigated using sitedirected mutagenesis, initially by constructing sets of four overlapping trinucleotide substitution mutations in the $5^{\prime}$ region of $\mathrm{U} 2$ (U2-2a-d) or the $3^{\prime}$ region of $U 6$ (U6-6a-d; Fig. 2A; Table 1). In addition to weakening U2/U6 helix II, mutations U2-2b, U2-2c, and U2-2d weaken or disrupt the lower portion of the intramolecular U2 stem I (Fig. 1A). The data in Figure 2, B and C, show that each of the eight trinucleotide substitutions tested supports growth indistinguishably from the wildtype alleles. Even larger disruptions of the U2 strand of helix II produced by two different 9-nucleotide substitutions (U2-9a and U2-9b) or complete disruption by an 11-nucleotide substitution (U2-11) had essentially no effect on growth (Fig. 3A; data not shown). These observations indicate that helix II is not essential for growth in this strain. However, helix II does actually form as shown by allele-specific suppression of other mutations (see below).

In contrast to the above observations, a larger disruption of the U6 strand of helix II, U6-9, which changes the identities of nucleotides 92-100, was lethal at all three temperatures (Fig. 3A). This lethality could not be suppressed by the pU2-9a or pU2-11 mutations, which would restore the potential for base-pairing at all or most of the positions involved in helix II (Fig. 3A, row 4; data not shown|. Combined with the observations above that the U2 strand of helix II can be disrupted completely without affecting growth, the severe phenotype of the U6-9 mutation suggested that this region of U6 snRNA might have another important function.

Alternatively, it was possible that the U6-9 mutation failed to be suppressed by pU2-9a because U6 -9 snRNA adopts irreversibly an unproductive conformation. If such a conformation interfered with the function of other components of the splicing machinery, the U6-9 mutation might be expected to confer a dominant-negative growth phenotype (Miraglia et al. 1991; Madhani and Guthrie 1994b). This seemed especially possible considering the previous observation of Madhani and Guthrie (1990) that a deletion of U6 nucleotides 90-98 conferred only a slightly cold-sensitive growth phenotype, suggesting that nucleotides $90-98$ of U6 snRNA are not involved in unique critical interactions. To test for a dominant-negative phenotype, a wild-type strain (W3031A) was transformed with pU6, pU6-9, or pRS315 (empty vector) and assayed for growth at $20^{\circ} \mathrm{C}, 23^{\circ} \mathrm{C}$, $30^{\circ} \mathrm{C}, 33^{\circ} \mathrm{C}$, and $37^{\circ} \mathrm{C}$ on selective medium. All three strains, including the heterozygote, grew indistinguishably from each other (data not shown), demonstrating that the U6-9 substitution is recessive and likely reflects loss of function.

This recessive loss of function is not simply attributable to decreased abundance of the U6-9 RNA. Although the level of U6 snRNA can decrease greatly as a second- 
A

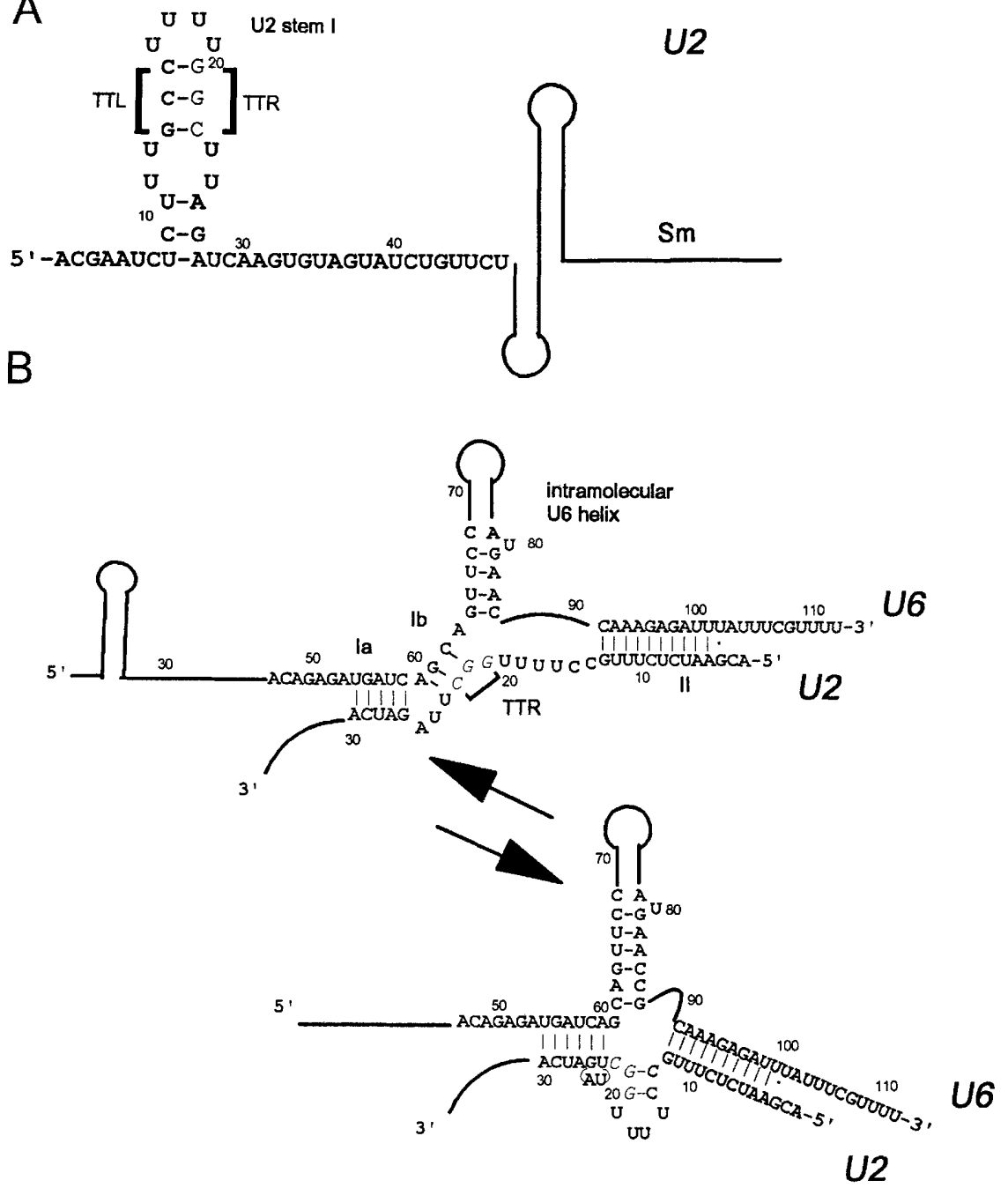

C

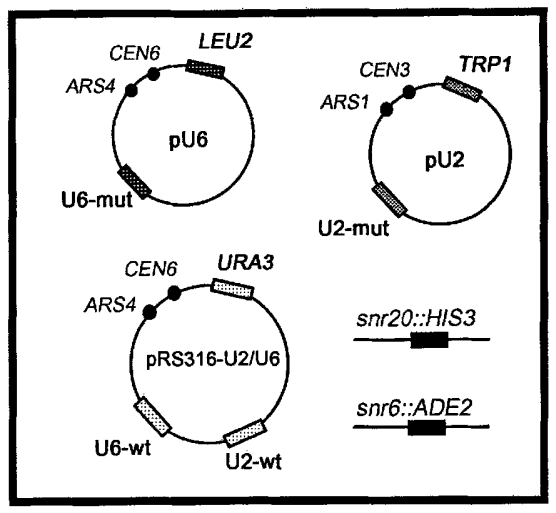

Figure 1. Dynamic conformations involving U2 and U6 snRNAs. $(A)$ Free U2 snRNA showing the 5 '-stem I structure (Keller and Noon 1985); the TTR region of U2 stem I is in lightface type. $(B)$ Schematic showing two potential $\mathrm{U} 2$ and $\mathrm{U} 6$ conformations in equilibrium (order is arbitrary); (top) U2/U6 helices $\mathrm{Ia}, \mathrm{Ib}$, and II fadapted from Madhani and Guthrie 1992); and (bottom) U2/U6 helix II and an elongated version of U2/U6 helix Ia and the intramolecular U2 stem I helix (adapted from Fortner et al. 1994). A tertiary interaction between U2-A25 and U6-G52 is not shown (Madhani and Guthrie 1994a). (C) YDF426 strain that is used to analyze $\mathrm{U} 2 / \mathrm{U} 6$ interactions. This strain is deleted for both SNR2O (snr20::HIS3) and SNR6 (snr6::ADE2). The deletions can be complemented by a single plasmid, pRS316-U2/ U6, or two plasmids, pU6-wt and pU2-wt. Mutations were generated on the pU6-wt and pU2-wt plasmids to create pU2-mut and pU6-mut. ary effect of mutations in certain other splicing genes le.g. prp3, prp4; Blanton et al. 1992; Galisson and Legrain 1993; Hu et al. 1994), primer-extension analyses suggested that the U6-9 mutant snRNA is only about twoto fourfold less abundant than wild-type U6 RNA (Fig. 3B; Table 2). Similarly, Madhani and Guthrie (1990) have found that three- to fivefold reduction in abundance of a U6 snRNA containing two point mutations causes no growth defect. Taken together, these observations suggest that the U6-9 mutation interferes with the function of other regions of U6 snRNA, perhaps by causing improper snRNP or spliceosome assembly, and that the $3^{\prime}$ region of U6 is involved in some essential function other than formation of helix II.

\section{U2/U6 helix Ib is not essential}

A possible reason for the dispensability of U2/U6 helix II is that it may be functionally redundant with some other interaction that could allow formation of a functional
U2/U6 complex. A logical candidate for such an interaction is U2/U6 helix Ia/Ib (see Fig. 1). A previous analysis has demonstrated that mutations in U2/U6 helix Ia (on either the U2 or U6 strand) are lethal, even in the presence of an intact U2/U6 helix II (Madhani and Guthrie 1992). Therefore, the most likely of the remaining candidates for a redundant element would be the proposed helix Ib. Single-base substitutions on the U6 strand of the proposed helix Ib have also been found to be lethal, although these assays were done in a strain in which the nonessential (Igel and Ares 1988; Shuster and Guthrie 1988) internal nucleotides 124-1067 of U2 snRNA had been deleted (Madhani and Guthrie 1992). We have confirmed that U6-G60C or C61G, which would disrupt the proposed helix $\mathrm{Ib}$, confers a lethal phenotype in our test strain, which contains the natural U2 gene (data not shown). In contrast, a trinucleotide substitution in U2, U2-triple top right (TTR), which would be expected to disrupt two of the three putative base pairs in helix Ib (Madhani and Guthrie 1992; as well as 
A



B

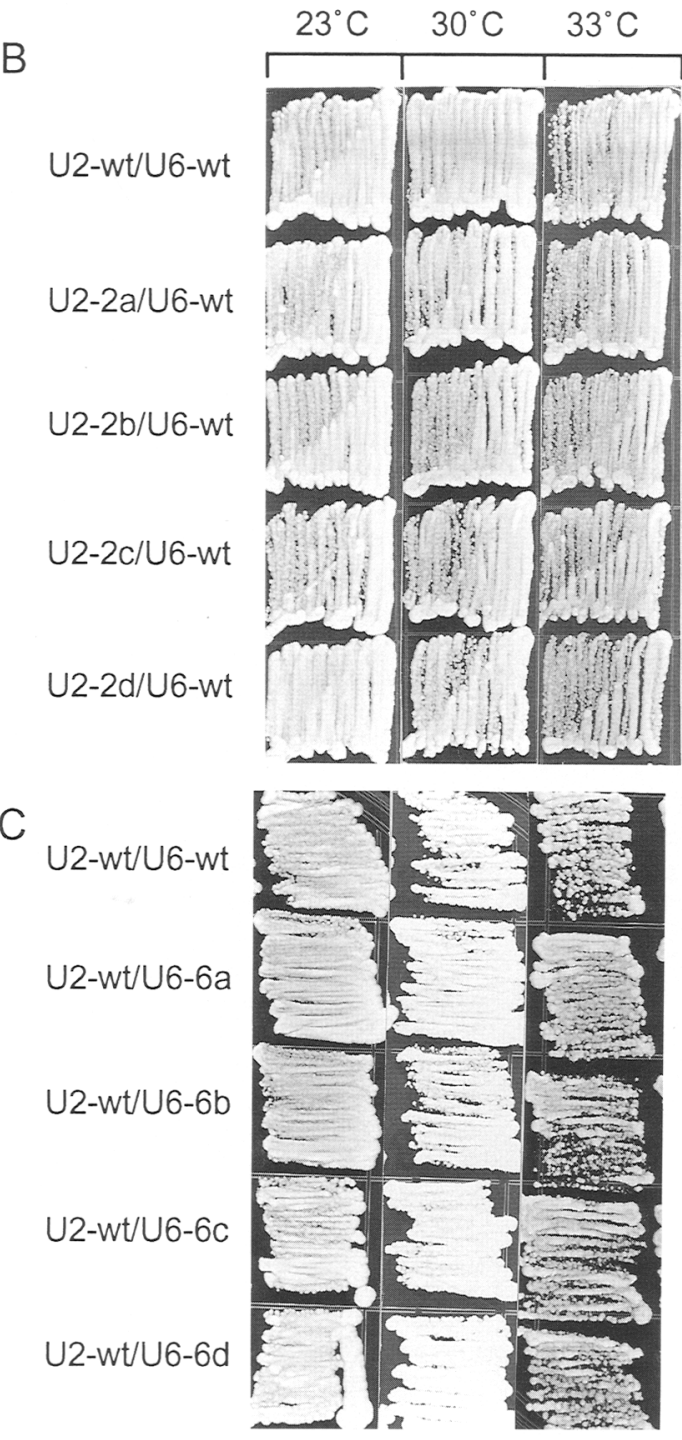

Figure 2. Growth phenotypes associated with triple mutations in U2/U6 helix II: FOA resistance. (A) Base-pairing involving the $5^{\prime}$ region of $\mathrm{U} 2$ and and the $3^{\prime}$ region of $\mathrm{U} 6$ forming helix II. The location of triple mutations in these regions of U2 and U6. Mutations are depicted in Table 1 . (B) Growth of YDF426 on FOA-containing selective medium at $23^{\circ} \mathrm{C}, 30^{\circ} \mathrm{C}$, and $33^{\circ} \mathrm{C}$ following transformation with pU6-wt and pU2-2a, pU2-2b, pU2-2c, and pU2-2d. Cells were grown for 4 days at $23^{\circ} \mathrm{C}, 2$ days at $30^{\circ} \mathrm{C}$, and 3 days at $33^{\circ} \mathrm{C}$. (C) Growth of YDF426 transformed with pU2-wt and pU6-6a; pU6-6b, pU6-6c, pU6-6d conditions as in $B$. the top portion of intramolecular U2 stem I; Table 1; Fig. 1A), grew indistinguishably from wild type (Fig 4A). This observation indicates that like helix II (above), the proposed helix Ib is not essential for mRNA splicing.

\section{U2/U6 helices $I b$ and II are redundant or synergistic}

Because helix Ib and II each can be disrupted individually without affecting growth, we investigated whether these helices might be two alternative, functionally redundant or synergistic components of the splicing machinery. We constructed mutants in which both helices Ib and II would be disrupted by combining U2-TTR with each of several mutations in helix II /e.g., U2-9a, U2-2a-d, U6$6 a-d)$. As shown above, in the absence of U2-TTR none of these mutations conferred growth defects /see Figs. 2B, C, and 3A). In contrast, when U2-TTR was combined with U2-9a, which disrupts 9 of the 11 putative base pairs in the U2 strand of helix II, the resulting strain grew very slowly at $23^{\circ} \mathrm{C}$ and not detectably at temperatures higher than $30^{\circ} \mathrm{C}$ (Fig. 3A). Trinucleotide disruptions caused by U2-2c or U2-2d and U2-TTR also conferred temperature-sensitive growth, but the effects were not as severe as with U2-9a (data not shown). Disruption of helix II on the U6 strand, by combining U2-TTR with U6-6c or U6-6d, also caused severe growth defects (Fig. $4 \mathrm{~A}$ ) at temperatures $>23^{\circ} \mathrm{C}$ or $30^{\circ} \mathrm{C}$, respectively. The growth defects resulting from combined disruption of helices Ib and II, but not from either one individually, show that neither helix alone is an essential component of the splicing machinery but are consistent with the

Table 1. U2 mutation and U6 mutations

\begin{tabular}{|c|c|c|c|}
\hline \multirow[t]{18}{*}{ U2 } & & & 22 \\
\hline & \multicolumn{2}{|l|}{$-w t$} & ACGAAUCUCUUUGCCUUUUGGC \\
\hline & \multicolumn{2}{|l|}{$-2 a$} & ACUCUUCUCUUUGCCUUUUGGC \\
\hline & \multicolumn{2}{|l|}{$-2 b$} & ACGAUCGUCUUUGCCUUUUGGC \\
\hline & \multicolumn{2}{|l|}{$-2 c$} & ACGAAUGAGUUUGCCUUUUGGC \\
\hline & \multicolumn{2}{|l|}{$-2 d$} & ACGAAUCAGAUUGCCUUUUGGC \\
\hline & \multicolumn{2}{|l|}{$-9 a$} & ACGAUCGAGACGCCCUUUUGGC \\
\hline & \multicolumn{2}{|l|}{$-9 b$} & ACGAUCGAUACGCCCUUUUGGC \\
\hline & \multicolumn{2}{|l|}{-11} & ACCUUCGAGACGCCCUUUUGGC \\
\hline & \multicolumn{2}{|l|}{$-\mathrm{TTL}$} & ACGAAUCUCUUUCGGUUUUGGC \\
\hline & \multicolumn{2}{|l|}{ - TTR } & ACGAAUCUCUUUGCCUUUUCCG \\
\hline & \multicolumn{2}{|c|}{ - TTL/TTR } & ACGAAUCUCUUUCGGUUUUCCG \\
\hline & \multicolumn{2}{|c|}{$-T T R+2 a$} & ACUUUUCUCUUUGCCUUUUCCG \\
\hline & \multicolumn{2}{|c|}{$-T T R+2 b$} & ACGAUCGUCUUUGCCUUUUCCG \\
\hline & \multicolumn{2}{|c|}{$-T T R+2 C$} & ACGAAUGAGUUUGCCUUUUCCG \\
\hline & \multicolumn{2}{|c|}{$-\mathrm{TTR}+2 \mathrm{C}^{\star}$} & ACGAAUUCUUUUGCCUUUUCCG \\
\hline & \multicolumn{2}{|c|}{$-\mathrm{TTR}+2 \mathrm{~d}$} & ACGAAUCAGAUUGCCUUUUCCG \\
\hline & \multicolumn{2}{|c|}{$-\mathrm{TTR}+9 \mathrm{a}$} & ACGAUCGAGACGCCCUUUUCCG \\
\hline \multirow[t]{7}{*}{ U6 } & \multirow{2}{*}{\multicolumn{3}{|c|}{$90 \quad 112$}} \\
\hline & $-w t$ & \multirow{2}{*}{\multicolumn{2}{|c|}{$\begin{array}{l}\text { UACAAAGAGAUUUAUUUCGUUUU } \\
\text { UACAAAGAGAAAGAUUUCGUUUU }\end{array}$}} \\
\hline & $\begin{array}{l}-w \\
-6 a\end{array}$ & & \\
\hline & $-6 b$ & \multicolumn{2}{|c|}{ UACAAAGACGAUUAUUUCGUUUU } \\
\hline & \multirow{2}{*}{$\begin{array}{l}-6 c \\
-6 d\end{array}$} & \multicolumn{2}{|c|}{ UACAAACUCAUUUAUUUCGUUUU } \\
\hline & & \multirow{2}{*}{\multicolumn{2}{|c|}{$\begin{array}{l}\text { UACAAUCUGAUUUAUUUCGUUUU } \\
\text { UAGCGUCUCGAUUAUUUCGUUUU }\end{array}$}} \\
\hline & & & \\
\hline
\end{tabular}






Figure 3. 5-FOA sensitivity of strains containing large substitutions in either or both of the U2 and U6 strands of helix II. (A) YDF426 was transformed with pU2-wt/pU6-wt, pU29a/U6-wt, pU2-wt/U6-9, pU2-9a/U6-9, pU2-11/U6-wt, $\mathrm{pU} 2-11 / \mathrm{U} 6-9$, and pU2-TTR $+9 \mathrm{a} / \mathrm{pU} 6-\mathrm{wt}$, and the resultant strains were tested for sensitivity to 5-FOA as in Fig. 2. (B) Steady-state levels of U2, U6, and U6-9 snRNA in a wildtype yeast strain. W303-1A was transformed with pRS315, pU6, and pU6-9 and primer-extension analysis was performed with primers specific to wild-type U2 snRNA, wildtype U6 snRNA, and U6-9 snRNA. The quantitation in Table 2. (C) Schematic of primer-extension products in B. Arrows indicate primers; sizes indicate expected length of cDNAs. U6- $\mathrm{wt}^{\prime}$ and U6-9' primers anneal to the same region of U6 transcript but are shifted by 2 nucleotides so that the two cDNAs can be distinguished on a $6 \%$ acrylamide gel. idea that these helices are redundant components or that the two helices act synergistically in the same pathway.

\section{Allele-specific suppression of \\ U6 mutations demonstrates the existence of helix II}

If the synergistic growth defects described above (Figs. $3 \mathrm{~A}$ and $4 \mathrm{~A}$ / were simply attributable to simultaneous disruption of helices $\mathrm{Ib}$ and II, we reasoned that it might be possible to construct allele-specific suppressors that would restore the potential for base-pairing in helix II, even though the restored helix would have different base pairs than the wild-type helix. Starting with mutants U2-TTR/U6-6c or U2-TTR/U6-6d we made additional base substitutions in $\mathrm{U} 2$ that would be complementary to the U6 trinucleotide substitutions. When the U2-2c mutation (complementary to U6-6c) was added to the combination of U2-TTR and U6-6c, this strain grew normally (Fig. 4B). Neither U2-2a, U2-2b, U2-2d, nor U2 $-2 c^{*}$ (which substituted the same three positions as U2-2c, but with bases that are not complementary to U6-6c), suppressed the growth defects (Fig. 4B). Similarly, addition of the U2-2d mutation /complementary to U6-2d) to the combination U2-TTR/U6-6d suppressed the growth defects (Fig. 4C). The noncomplementary substitutions U2-2a, U2-2b, U2-2c, and U2-2c* did not suppress; they grew even more poorly than the parental strain. This allele-specific suppression provides strong support for the existence and functional importance of helix II. 
Table 2. Relative amounts of U2, U6, and U6-9 snRNAs inW303-1A

\begin{tabular}{lccc}
\hline & + pRS315 & + pU6 & + pU6-9 \\
\hline U2 & 1.0 & 1.0 & 1.0 \\
U6-wt & 3.7 & 5.7 & 3.4 \\
U6-9 & 0 & 0 & 1.1 \\
U6-total & 3.7 & 5.7 & 4.5 \\
\hline
\end{tabular}

W303-1A transformed with each of these plasmids, total RNA isolated, and the relative amount of each snRNA determined from its cDNA after primer extension analysis using 1.0 pmole of each of three primers (DF108, DF150, and DF151). Primers were determined to be in saturation from preliminary experiments and were used at the same specific activity. Relative amounts of ech cDNA were normalized to U2 cDNA. The Molecular Dynamics Phosphorlmager was used to quantitate relative amounts of each RNA.

The temperature-sensitive mutants U2-TTR/U6-6c, $\mathrm{U} 2-\mathrm{TTR}+2 \mathrm{c} / \mathrm{U} 6-\mathrm{wt}$, and U2-TTR/U6-6d, U2$\mathrm{TTR}+2 \mathrm{~d} / \mathrm{U} 6-\mathrm{wt}$ and the corresponding suppressors, $\mathrm{U} 2-\mathrm{TTR}+2 \mathrm{c} / \mathrm{U} 6-6 \mathrm{c}$ and $\mathrm{U} 2-\mathrm{TTR}+2 \mathrm{~d} / \mathrm{U} 6-6 \mathrm{~d}$, which restore helix II, provided a way of investigating potential RNA splicing defects associated with these mutations. These strains, a wild-type control, and others (Fig.5 A and $\mathrm{B})$ were grown at the permissive temperature $\left(23^{\circ} \mathrm{C}\right)$ in liquid medium for $12-18 \mathrm{hr}$ and then were shifted to the restrictive temperature $\left(37^{\circ} \mathrm{C}\right)$. The data in Figure 5, $A$ and $B$, show that following shift to $37^{\circ} \mathrm{C}$, the U2-wt/ U6-wt strain continued to grow exponentially for as long as the experiment was monitored (24 hr), as expected. In contrast, U2-TTR/U6-6c, and U2-TTR $+6 \mathrm{c} /$ U6-wt stopped growing within 5-6 hr. The suppressor, U2-TTR + 2c/U6-6c, grew indistinguishably from wild type at $37^{\circ} \mathrm{C}$. Similarly, U2-TTR/U6-6d and U2$\mathrm{TTR}+2 \mathrm{~d} / \mathrm{U} 6-\mathrm{wt}$ stopped growing within $8 \mathrm{hr}$. The suppressor strain U2-TTR $+2 \mathrm{~d} / \mathrm{U} 6-6 \mathrm{~d}$ grew exponentially for at least $24 \mathrm{hr}$ following temperature shift (Fig. 5B), although at a slightly slower rate than the wild type.

To investigate possible splicing defects, RNA was isolated from all of the strains used in Figure 5, A and B, following growth at the permissive temperature $\left(23^{\circ} \mathrm{C}\right)$ or following a shift to $37^{\circ} \mathrm{C}$ for 1,2 , or $6 \mathrm{hr}$. We studied transcripts of the two genes encoding U3 snRNA IU3A and $U 3 B \mid$, the gene encoding ribosomal protein 51 (RP51A), and the gene encoding actin (ACT1); transcripts of these genes have been used in several previous studies of other splicing mutants (Vijayraghavan et al. 1989; Ares and Igel 1990; Miraglia et al. 1991; Madhani and Guthrie 1992; Wells and Ares 1994). The slow-growing strains showed a slight increase (up to twofold) in the ratio of precursor to mature RNA in some experiments. However, this observation was not reproducible in all experiments (data not shown). The magnitude of the splicing defects was much less than that observed with temperature-sensitive mutants in protein components of the spliceosome (e.g., prp2-1; Fig. 5C). Severe growth defects in the absence of splicing defects have been noted previously (Patterson and Guthrie 1987; Igel and Ares
1988; Seraphin and Rosbash 1989; Ares and Igel 1990; Madhani and Guthrie 1992; Patterson and Guthrie 1992; see Discussion). The ratio of precursor to mature RNAs in the suppressor strains U2-TTR $+2 \mathrm{c} / \mathrm{U} 6-6 \mathrm{c}$ and U2TTR + 2d/U6-6d was essentially the same as in the wildtype strain (Fig.5C; data not shown).

Some of the bases in the U2 strand of the proposed helix Ib, including some of those changed by the U2TTR mutation, are involved in an alternative structure that forms U2 intramolecular stem I (Fig. 1). Thus, the growth defects that we have ascribed above to simultaneous disruption of helices Ib and II hypothetically could be the result of the combined disruption of three helices: Ib, II, and U2 stem I. However, because the mutation U2-TTR, which disrupts both the proposed helix Ib and U2 stem I, does not confer a growth defect (Figs. 4A and 6A), we conclude that of the three helices under consideration, helix II alone is sufficient for growth.

To investigate whether $\mathrm{U} 2$ stem I and helix II could both be disrupted simultaneously without affecting growth, we disrupted U2 stem I with a mutation, U2triple top left (TTL), that would not affect helix Ib (see Fig. 1). The U2-TTL mutant grew normally in the presence of wild-type U6 and also in presence of the U6-6c mutation, which disrupts helix II (Fig. 5A,B). These observations show that like helix II, the proposed helix Ib alone is also sufficient for growth.

We tried to determine whether U2 stem I alone could also be sufficient for growth by attempting to suppress the growth defect of U2-TTR/U6-6c by including U2TTL. This combination of mutations would be expected to restore pairing in $\mathrm{U} 2$ stem I but would leave helices Ib and II disrupted. This strain did not grow; however, the interpretation of this lack of suppression is complicated by the observation that the control strain U2-TTL/TTR, in the presence of wild-type U6, showed an unexpected slight temperature-sensitive grow th defect (Fig. 6B). This suggests that the U2-TTL mutation may interfere with U2 function in an undetermined manner.

\section{Discussion}

We have investigated the importance of the proposed U2/U6 helices Ib and II for normal growth and premRNA splicing in yeast. In the absence of other mutations, all of the mutations in the U2 strand of helix II that we studied caused no growth defects at $23^{\circ} \mathrm{C}-37^{\circ} \mathrm{C}$. This lack of phenotype is consistent with previous results that revealed no or minor growth defects when the $5^{\prime}$ region of yeast $U 2$ was exchanged with the $5^{\prime}$ region of human U2 (Shuster and Guthrie 1990; Miraglia et al. 1991), when nucleotides 3-13 were deleted from the 5' region of U2 (Madhani and Guthrie 1994b) or nucleotides 90-98 were deleted from the 3' region of U6 (Madhani and Guthrie 1990). These observations show that helix II is not essential for normal growth.

Although helix II is not essential, our data do not justify the conclusion that helix II has no functional role. We have found that two different trinucleotide substitution mutations either in the U2 or U6 strand of helix II, 
A

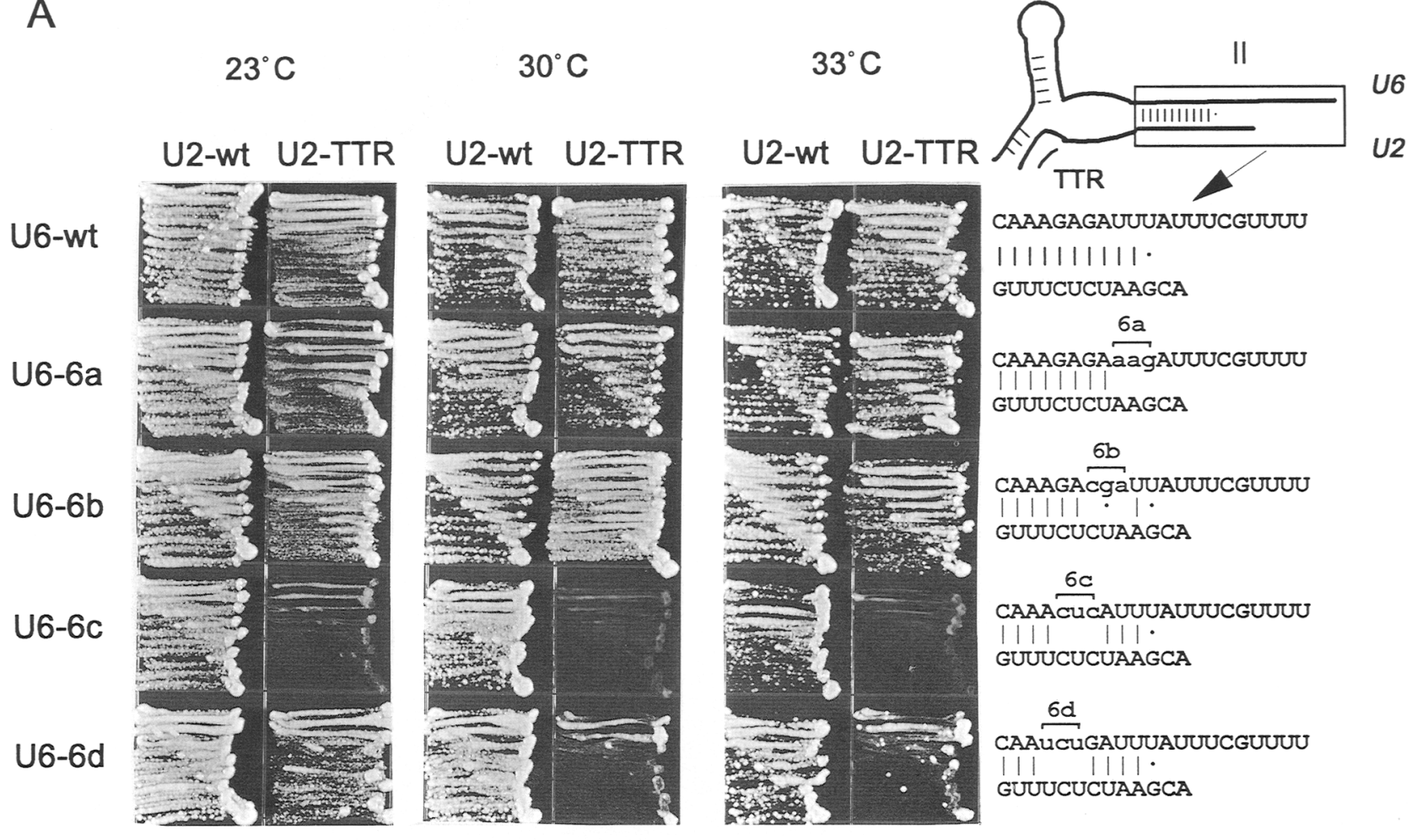

B

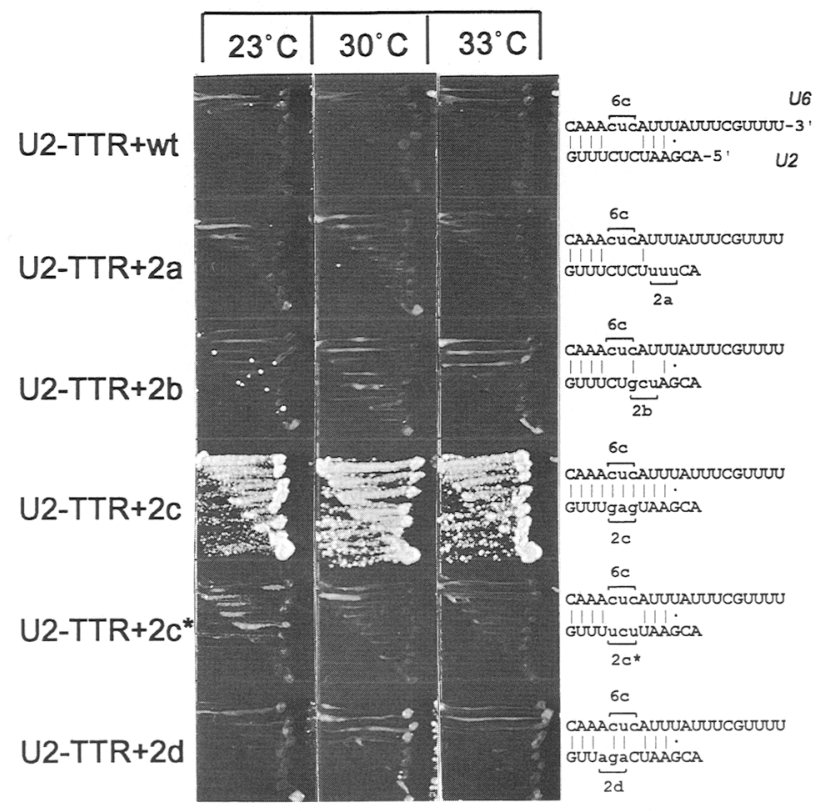

C

U2-TTR+wt

U2-TTR+2a

U2-TTR+2b

U2-TTR+2C

U2-TTR+2C

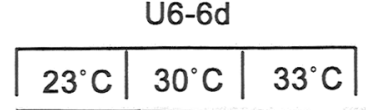

U2-TTR+2d



6aAucugauduautucGuUUU Gurucucuuurca

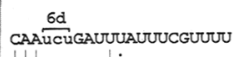
GUUUCUgCuAGCA $2 b$ caAucugauruautucguruo GUUUgaguaAgCa $2 c$ caAucugauruaturucgurur guvUucuUAagca 20 canaduganuuaurucgurur guvagacuaAcca

Figure 4. (A) 5-FOA sensitivity of YDF426 transformed with U6-wt, U6-6a, U6-6b, U6-6c, U6-6d, and U2-wt or U2-TTR. Growth conditions are as in Fig. 2. (B) Allele-specific suppression of U2-TTR/U6-6c by restoring Watson-Crick base-pairing in helix II. Strains were transformed and tested as in Fig. 2. The small number of colonics in column 1 are spontaneous outgrowths attributable to reversion or recombination with the shuffling plasmid (see also Miraglia ct al. 1991). (C) Allele-specific suppression of U2-TTR/U6d by restoration of Watson-Crick base-pairing in helix II. Strains were tested and grown as in Fig. 2. The small number of colonies in column 3 are as described above.

when combined with phenotypically silent mutations that disrupt the U2 strand of the proposed helix $\mathrm{Ib}$, pro- duced inviable strains (Fig. 4). In both cases, the synthetically lethal phenotype could be suppressed by restoring 
Figure 5. In vivo growth and splicing phenotypes associated with wild-type, mutant, and suppressor strains in $\mathrm{U} 2$ and U6. $|A|$ Growth curves of U2-wt/U6-wt, U2-2c/U6-wt, U2-TTR + 2c/U6-6c, U2TTR/U6-6c, U2-TTR/U6-wt, U2-wt/ U6-6c, and U2-TTR + 2c/U6-wt showing temperature sensitivity of U2-TTR/U6$6 \mathrm{c}$ and U2-TTR $+2 \mathrm{c} / \mathrm{U} 6-\mathrm{wt}$ and suppression by U2-TTR $+2 \mathrm{c} / \mathrm{U} 6-6 \mathrm{c}$. Cultures were grown for $12-18 \mathrm{hr}$ to early log phase $\left\{A_{600}=0.2-0.4\right\}$ and then shifted to $37^{\circ} \mathrm{C}$ at time $=0$. Cell growth was monitored for $12 \mathrm{hr}$. Cells were harvested at 1,2 , and $6 \mathrm{hr}$, and RNA was isolated. $(B)$ Growth curves of U2-wt/U6-wt, U2-2d/U6-wt, $\mathrm{U} 2-\mathrm{TTR}+2 \mathrm{~d} / \mathrm{U} 6-6 \mathrm{~d}, \quad \mathrm{U} 2-\mathrm{TTR} / \mathrm{U} 6-6 \mathrm{~d}$, U2-TTR/U6-wt, U2-wt/U6-6d, and U2TTR $+2 \mathrm{~d} / \mathrm{U} 6-\mathrm{wt}$ showing temperature sensitivity of U2-TTR/U6-6d, and U2$\mathrm{TTR}+2 \mathrm{~d} / \mathrm{U} 6-\mathrm{wt}$, and suppression by $\mathrm{U} 2-$ $\mathrm{TTR}+2 \mathrm{~d} / \mathrm{U} 6-6 \mathrm{~d}$. Conditions as in $A .(C)$ In vivo splicing analysis of $U 3 A$ and $U 3 B$ using RNA isolated from cells harvested at $6 \mathrm{hr}$. RNAs for $C$ were detected by primer extension using primers complementary to exon 2 of U3.
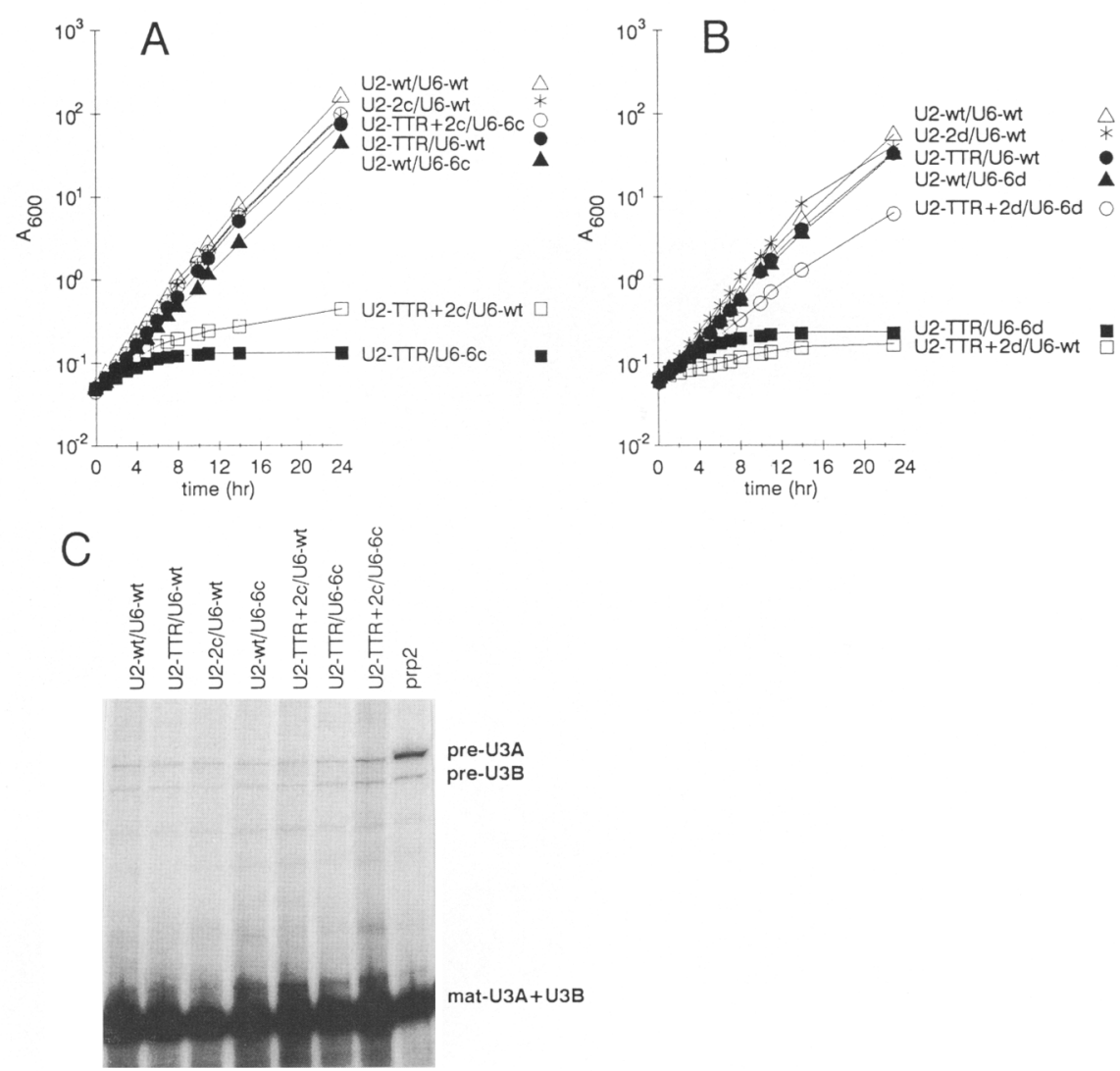

base-pairing in helix II with compensatory mutations in the appropriate region of $\mathrm{U} 2$. In contrast, eight noncompensatory mutations in this region of U2 did not suppress. The mutations disrupting helix II could also be placed on the U2 strand and suppressed by the complementary mutations in U6 (Fig. 5). This allele-specific suppression provides strong genetic evidence that the 5 ' region of $\mathrm{U} 2$ and the $3^{\prime}$ region of $\mathrm{U} 6$ do base-pair to form helix II in $S$. cerevisiae and that this helix is involved in functions that are essential for growth.

Given the very striking growth defects caused by disruption of helices $\mathrm{Ib}$ and II, it is suprising that we were unable to detect a convincing splicing defect using four different intron-containing pre-mRNAs $(U 3 A, U 3 B$, $A C T 1$, and RP51A). A similar lack of correlation between the magnitude of the splicing defects and the severity of the growth defect has been observed with other mutations in snRNAs (Patterson and Guthrie 1987; Igel and Ares 1988; Seraphin and Rosbash 1989; Ares and Igel 1990; Madhani and Guthrie 1992; Patterson and Guthrie 1992). Disproportionate growth defects could be attributable to the cumulative effects of slight reduction in the splicing of many introns or to the inefficient splicing of a few particular mRNAs encoding low-abundance or unstable proteins (Seraphin and Rosbash 1989; Ares and Igel 1990). It is also possible that spliceosomal snRNAs are involved in essential functions in addition to splicing.

In HeLa cells mutational disruption of helix II alone has been shown to reduce splicing of two different introns in engineered reporter pre-mRNAs (Datta and Weiner 1991; Wu and Manley 1991). The apparent importance of helix II in HeLa cells, but not in yeast, may reflect authentic species-specific differences in the requirement for helix II, or it may reflect different sensitivities of the assay sytems used for yeast and HeLa cells. Both HeLa assays included altered sequences of U2 and pre-mRNA at the branchpoint to obtain specificity. It is possible that these sequence changes /Wu and Manley 1989, 1991; Zhuang and Weiner 1989; Datta and Weiner 1991, 19931, each innocuous individually, actually enhanced the phenotype of the U2 and U6 mutations in helix II in a manner that is analogous to the synthetic lethality that we observed with mutations in yeast (see above; Wells and Ares 1994).

Differences in sensitivity even between the two HeLa splicing assays [SV40 (Wu and Manley 1991, 1992) and $\beta$-globin introns (Datta and Weiner 1991, 1993)] have already been noted. A mutation altering the identical bases may affect splicing in a very sensitive assay $/ \mathrm{Wu}$ and Manley 1992) but not in a less sensitive one (Datta and Weiner 1991). In several instances where a mutation in a snRNA or splicing gene has resulted in little or no splicing difference in endogenous introns, sensitive poorly spliced reporter constructs have been used to demonstrate an in vivo splicing defect (e.g., Legrain and Rosbash 1989; Liao et al. 1990; Frank and Guthrie 1992 Lesser and Guthrie 1993; Umen and Guthrie 1995). Sim- 

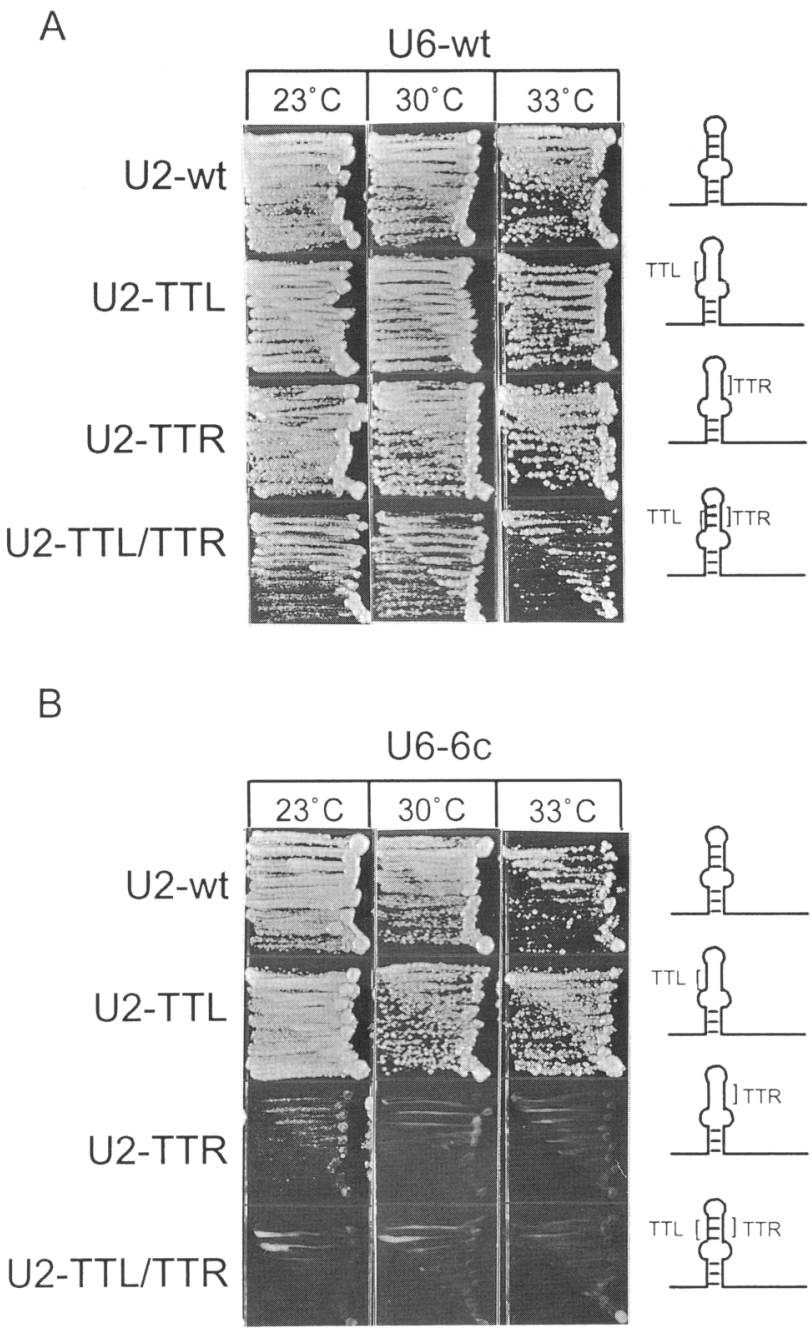

Figure 6. Base-pairing in U2-stem I does not restore cell viability in the presence of U6-6c. (A) Disruption of U2-stem I in the presence of wild-type U6. YDF426 was cotransformed with pU6-wt and pU2-wt, pU2-TTL pU2-TTR, pU2-TTR/TTL and was tested as in Fig. 2. (B) Disruption of U2-stem I in the presence of U6-6c. YDF426 was cotransformed with pU6-6c and pU2-wt, pU2-TTL pU2-TTR, and pU2-TTR/TTL and was tested as in Fig. 2.

ilarly, in vivo and in vitro assays in yeast have different sensitivities, e.g., U2-TTR does not show a growth defect in vivo (Figs. 4-6), but the same mutation when assayed in vitro (tmIU'; McPheeters and Abelson 1992) with reconstituted $U 2$ and the $A C T 1$ intron shows a first-step splicing defect. Unfortunately, the use of splicing assays that differ vastly in sensitivity makes it difficult to make quantitative comparisons of the effects of mutations even in the same organism.

During the course of this study, we also found that certain mutations that disrupt the U2 strand of proposed helix Ib (e.g., U2-TTR; Fig. 4) were not lethal in the absence of other mutations. This demonstrates that the proposed helix Ib is not essential. However, in the pres- ence of mutations that disrupted helix II, disruption of the nucleotides in the proposed helix Ib was lethal. We were unable to suppress these mutations with complementary substitutions in the U6 strand of the proposed helix Ib. The complementary U6 nucleotides have been shown to have alternative interactions, for example, with U4 snRNA (Brow and Guthrie 1988), which would have been disrupted by the substitutions we used to restore complementarity to U2. Taken together, these experiments demonstrate that neither the proposed helix Ib nor helix II alone is essential but that the two play redundant or synergistic roles. Other nonessential interactions have been indentified previously in yeast $\mathrm{U} 1, \mathrm{U} 2$, and U4 snRNAs (Igel and Ares 1988; Shuster and Guthrie 1988; Liao et al. 1990; Silicano et al. 1991; Stutz et al. 1993; Wells and Ares 1994; Hu et al. 1995). Silent mutations affecting these interactions are often lethal when combined with a second mutation in the same RNA /Fig. 5A, B; Madhani and Guthrie 1992; Stutz et al. 1993; Wells and Ares 1994) or with a mutant PRP, SLU, or MUD protein (Frank and Guthrie 1992; Liao et al. 1993; Ruby et al. 1993; Wells and Ares 1994; Abovich et al. 1994). Nonessential, possibly redundant, interactions have also been observed in known catalytic RNAs. For example, two different short helices, P9.0 and P10, can contribute to specifying the $3^{\prime}$-splice site in group I introns (Burke et al. 1990; Michel et al. 1990; Suh and Waring 1990). All of those observations serve to emphasize that caution should be used in concluding that a particular interaction is not involved in a particular function simply because it is not essential for that function.

In contrast to the redundancy observed in yeast, mutations in either helix II or in helix Ib result in splicing defects in HeLa cells (Datta and Weiner 1991; Wu and Manley 1991; Sun and Manley 1995) suggesting that these helices individually may be critical in HeLa cells. In HeLa cells, helix II has been demonstrated directly by allele-specific suppression (Datta and Weiner 1991; Wu and Manley 1991), although similar experiments have yet to demonstrate helix Ib (Sun and Manley 1995). Mutating the third nucleotide in the proposed human helix Ib, U6-A53 (yeast U6-A59) results in small splicing defects that are not suppressible by restoring base-pairing in U2 (Sun and Manley 1995). Other mutations in the U2 strand of the proposed Ib helix that also disrupt intramolecular U2 stem I can be suppressed by mutations that restore U2 stem I (Sun and Manley 1995). Similarly, mutations on the U6 strand of the proposed helix Ib that also disrupt an intramolecular helix can be suppressed by mutations that restore the intramolecular U6 helix (Sun and Manley 1995). If helix Ib exists in humans or in yeast, it may well be redundant with U2-stem I and the intramolecular U6 helix. In yeast, only the U6-A59/U2U23 base pair (out of three) has been demonstrated by mutation/suppression experiments (Madhani and Guthrie 1992). The possibility remains that mutations that disrupt the other proposed base pairs may actually (or alternatively) confer their phenotype by disrupting other structures. 
Our data are relevant to current models of RNA-RNA interactions in the spliceosome and group II introns (Madhani and Guthrie 1992; 1994c; Chanfreau and Jacquier 1994; Boulanger et al. 1995; Yu et al. 1995). In these models helix Ib is proposed to be the spliceosomal counterpart of a portion of domain $\mathrm{V}$ of group II selfsplicing introns; these functionally analogous domains are thought to contain part of the active site for splicing of each type of intron. Our observations that helix II and the nucleotides in the proposed Ib play synergistic or redundant roles in splicing indicate that neither is an essential component of the active site. The functional redundancy of these interactions may be similar to the observation that several of the conserved domains in group II introns can be disrupted or deleted without abolishing splicing in vitro (Jarrell et al. 1988; Bachl and Schmelzer 1990; Koch et al. 1992; Michels and Pyle 1995).

That neither helix Ib nor II is essential, but that both are involved in splicing, suggests that they are both part of a larger structure containing elements that may act cooperatively. This multiplicity of structural associations might ensure that critical interactions take place, play a role in the fidelity of certain processes, and allow the splicing machinery to accommodate a variety of introns as well as trans-acting factors. These interactions may facilitate and regulate splicing in a variety of environments and during development.

\section{Materials and methods}

Yeast and bacterial methods and strains

Escherichia coli XL1-Blue supE44 hsdR17( $\left.\mathrm{r}_{\mathrm{k}_{-}}, \mathrm{m}_{\mathrm{k}_{+}}\right) \operatorname{rec} A 1$

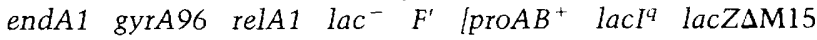
Tn 10:(tet $\left.\left.{ }^{\mathrm{r}}\right)\right]$ and DH5 $\alpha \mathrm{F}^{\prime} \phi 80 \mathrm{~d} l a c Z \Delta M 15 \Delta($ lacZYA-argF|U169 deoR recA1 endA1 hsdR17 $\left(\mathrm{r}^{-}{ }_{\mathrm{k}}, \mathrm{m}^{+}{ }_{\mathrm{k}}\right)$ supE44 $\lambda^{-}$thi-1 gyrA96 relA1 were used for propagating yeast shuttle vectors and for the isolation of DNA for subcloning and yeast transformations. $E$. coli JM10l supE, thi $\Delta($ lac-proAB $) \mathrm{F}^{\prime}\left[\right.$ traD36 proAB ${ }^{+}, \operatorname{lacl}^{q}$ 'lacZSM15] and $E$. coli CJ236 dut1 ung1 thi-1 relA1/ $\mathrm{pC}] 105\left(\mathrm{cam}^{\mathrm{r}} \mathrm{F}^{\prime}\right\}$ were the host strains for single-stranded nonuracil and uracil-containing DNAs, respectively. XL1-Blue and MC1066 [S(lacIPOZYA)74 galE15 galK16 strA ${ }^{\mathrm{r}}$ hsdR trpC9830 leuB6 pyrF74:: $\left.\operatorname{Tn} 5\left(\mathrm{Km}^{\mathrm{r}}\right)\right]$ were used as the host strains when isolating plasmid DNAs from yeast strains.

S. cerevisiae strains: LP1 12 (MATa/ $\alpha$ his3-11,52/his3-11,52 leu2-3,112/leu2-3,112 trp1-1/trp1-1 ura3-52/ura3-52 ade2-1/ ade2-1 can1-100/can1-100) and the isogenic haploid strains W303-1A (MATa his3-11,52 leu2-3,112 trp1-1 ura3-52 ade2-1 can1-100) and W303-1B (MAT $\alpha$ his3-11,52 leu2-3112 trp1-1 ura3-52 ade2-1 can1-100) were the parental strains and used for all subsequent strain constructions. YDFl4 (MATa snr20::HIS3 his3-11,52 leu2-3,112 trp1-1 ura3-52 can1-100 pDF9l) and YDF16 (MAT $\alpha$ snr20::HIS3 leu2-3,112 his3-11,52 trp1-1 ura3. 52 can1-100 pDF91) were used for the analyses of U2 mutants. YDF341 (MAT ade2-1 his3-11,52 leu2-3,112 snr6::ADE2 trp1-1 ura3-52 can1-100 pRS316-U6) and YDF339 (MAT $\alpha$ ade2-1 his311,52 leu2-3,112 snr6::ADE2 trp1-1 ura3-52 can1-100 pRS316U6) were used for the analyses of U6 mutants. Two strains were constructed that contained a disruption of both SNR20 and SNR 6 by selecting segregants of a cross between YDF14+pU2 with YDF339 + pU6 to form YDF357 (MATa ade2-1 his 3-11,52 snr20::HIS3 leu2-3,112 snr6::ADE2 trp1-1 ura3-52 can1-100 pU2 pU6. YDF357 was subsequently transformed with pRS316$\mathrm{U} 2 / \mathrm{U} 6, \mathrm{pU} 2$ and pU6 were subsequently lost, and the resulting parental strain was designated YDF426. All U2 and U6 mutants were transformed into this strain and subsequently tested for sensitivity to 5 -FOA (Boeke et al. 1987 ) at $23^{\circ} \mathrm{C}, 30^{\circ} \mathrm{C}$, or $33^{\circ} \mathrm{C}$. Higher temperatures were not used because in the presence of 5-FOA, the parental strain YDF426 grows poorly at $37^{\circ} \mathrm{C}$.

All $E$. coli strains were grown in LB media, and yeast strains were grown in yeast extract/peptone dextrose (YPD) broth or in selective dropout media according to Rose et al. (1990). E. coli DNA polymerase (Klenow), T4 DNA ligase, T4 polynucleotide kinase, Superscript II, T7 DNA polymerase, and Taq polymerase were obtained from BRL. Some batches of AMV reverse transcriptase were obtained from Seikagaku, Inc. Sequenase was obtained from U.S. Biochemical. $\left.\left[\alpha-{ }^{32} \mathrm{P}\right] \mathrm{dATP}, \mid \gamma^{-32} \mathrm{P}\right] \mathrm{dATP}$, and $\left[\alpha{ }^{-35}\right.$ S $]$ dATP were obtained from NEN. Unlabeled deoxynucleotides and dideoxynucleotides were obtained from BRL or U.S. Biochemical.

\section{Plasmid constructs}

An 11.5 -kb clone containing SNR20 was cloned from a Sau3AI partial library made in pAPS2 (Percival-Smith and Segall 1986; pDF57). A 2.4-kb SalI-Smal fragment containing SNR20 was cloned into YCp30 (John Carbon, University of California at Santa Barbaral at the SalI and BamHI site after end-filling the BamHI site with deoxynucleotides and Klenow. A 4.8-kb SalIECORI partial fragment containing SNR20/TRP1/ARS/CEN3 was subsequently recloned into pTZ18R at the Sall and EcoRI sites. The subsequent $7.65-\mathrm{kb}$ pU2 was used as a wild-type $\mathrm{TRP}^{+}$parental plasmid for subsequent experiments involving U2 or to make single-stranded DNA for site-directed mutagenesis. A second plasmid, pDF91, was constructed by subcloning a 3.3-kb Sall-EcoRI fragment containing SNR2O and and CEN3 from pDF87 between the Sall and EcoRI sites of pFL34 [F. Lacroute, Centre National de la Recherche Scientifique (CNRS), Gif-sur-Yvette, Francel to produce pDF64. A 300-bp Sall-XhoI fragment containining CAN1 was then cloned into the the Sall site of pDF64 to produce pDF83. An 810-bp EcoRI-HindIII fragment containing ARS1 (YCp30) was then cloned into the SalI site of pDF83 after end-filling and the addition of Sall linkers to produce pDF91. The 8.3-kb URA3-based plasmid was then subsequently renamed PSFL-U2.

SNR6 was cloned by symmetric PCR, and it was cloned in pRS316 (Sikorski and Hieter 1989) as a BamHI-EcoRI fragment (Hu et al. 1994) to generate pRS316-U6. The $1.1-\mathrm{kb}$ fragment was subsequently subcloned into pRS315 (Sikorski and Hieter 1989 ) to generate pU6. This plasmid was used to make singlestranded DNA for site-directed mutagenesis. pRS316-U6 was constructed by subcloning the 1.1-kb BamHI-EcoRI fragment of SNR6 from pU6 into the BamHI and EcoRI sites of pRS316. A 2.4-kb Sall-Smal/EcoRI fragment containing SNR2O was subsequently subcloned in pRS316-U6 to produce a U2/U6 shuffling plasmid, pRS316-U2/U6.

\section{Gene disruptions of SNR20 and SNR6}

Disruption of SNR20 A 6.6-kb XbaI-EcoRI fragment from pDF57 was subcloned into the $X b a \mathrm{I}$ and EcoRI sites of pUC18 to form pDF69. pDF69 was digested with Sall and SmaI, and the U2 gene was replaced with a $1.7-\mathrm{kb}$ Sall-SmaI fragment containing HIS3 (pDF31) to form pD72. This fragment previously had been subcloned into the BamHI site of pUC18 as a BamHI fragment and before it was isolated as a SalI-SmaI fragment. $S$. 
cerevisiae LP112 (MATa/ $\alpha$ his3-11,52/his3-11,52 leu2-3,112/ leu2-3,112 trp1-1/trp1-1 ura3-52/ura3-52 ade2-1/ade2-1 can1$100 /$ can 1-100) was transformed with a $5.9-\mathrm{kb}$ Xbal-EcoRI fragment of pDF72 to form the heterozygous diploid YDF201(MATa/ $\alpha$ snr20::HIS3/his3-11,52 leu2-3,112/leu2. 3,112 trp1-1/trp1-1 ura3-52/ura3-52 ade2-1/ade2-1 can1-100/ can1-100).

Disruption of SNR6 $A$ 2.4-kb BgIII-BglII fragment was inserted into the unique $B c$ II site of SNR6 in pYF1114, and a 3.5-kb BamHI-HindIII fragment containing the disrupted SNR6 gene with LEU2 was used to transform LP1 12 to form $\mid M A T \mathbf{a} / \alpha$ his3-11,52/his3-11,52 snr6::LEU2/leu2-3,112 trp1-1/trp1-1 ura3-52/ura3-5 ade2-1/ade2-1 can1-100/can1-100).

\section{Transformations and mutagenesis}

Competent $E$. coli cells were prepared by the calcium chloride method (Sambrook et al. 1989). Yeast cells were prepared by the LiAc method of Ito et al. (1987), or Hill et al. (1991). Site-directed mutations were made using the method of Kunkel et al. (1987) starting with pU6-wt and pU2-wt.

\section{Growth curves and temperature shift analysis}

Haploid strains were grown at $23^{\circ} \mathrm{C}$ in $100 \mathrm{ml}$ of liquid selective medium (Rose et al. 1990). At $A_{600}=0.2-0.6$ cells, were pelleted and resuspended in prewarmed $\left(37^{\circ} \mathrm{C}\right)$ medium at $A_{600}=0.05-$ 0.075 . Cell growth was monitored regularly at O.D.600. Growth curves were done at $33^{\circ} \mathrm{C}$ and $37^{\circ} \mathrm{C}$ with essentially the same result except that $\mathrm{U} 2-\mathrm{TTR}+2 \mathrm{~d} / \mathrm{U} 6-\mathrm{wt}$ was still growing exponentially after $24 \mathrm{hr}$. Only the $37^{\circ} \mathrm{C}$ growth curves are shown. Experiments were limited to $<24 \mathrm{hr}$ in liquid culture to minimize the selection for suppressors.

\section{Quantitation of U2, U6, and U6-9 RNAS}

pRS315, pU6, and pU6-9 were introduced into W303-1A, and cells were plated onto selective medium. Cells were grown until mid-log phase in liquid medium at $30^{\circ} \mathrm{C}$. W303-1 A was chosen so that the relative amount of mutant snRNAs could be normalized to chromosomal amounts of wild-type U2 and U6 snRNAs. RNA was extracted from all three strains (see below). Primer-extension experiments were performed with primers specific for U2-wt, U6-wt, and U6-9nt: U2-wt', U6-wt', and U6-9nt'. The sequence of the primers was U2-wt' (Ares 1986), 5'-GGTAATGAGCCTCATTGAGG-3'; U6-wt' (Brow and Guthrie 1988|, 5'-AATAAATCTCTTTGTAAAACGG-3'; and U6-9', 5'-TAATCGAGACGCTAAAACGG-3'. The sizes of the products for U2-wt' $=90$ nucleotides, U6- $\mathrm{wt}^{\prime}=105$ nucleotides, and U6-9' $=103$ nucleotides. Preliminary experiments using $0.01-1$ pmole of primer were performed with individual primers to determine the amount of primer required to produce the maximum amount of cDNA in $2 \mathrm{hr}$ (saturation). For quantitative determination of U6-wt, U6-9, and U2-wt snRNAs, we repeated the primer-extension extension experiments using 2 $\mu \mathrm{g}$ of total RNA and measured the amount of all three cDNAs produced as a function of saturating primer (1 pmole each). cDNAs were separated on a $6 \%$ polyacrylamide gel, dried, and exposed to a phosphorimaging screen. Quantitation was performed on the Molecular Dynamics PhosphorImager.

\section{RNA isolation and analysis}

Total RNA was purified from early to mid-log phase cells using the phenol and glass bead method; RNA was analyzed by primer extension using the method described by Fouser and Friesen (1986). The following 3 '-end-labeled primers were used: RP51A (Teem and Rosbash 1983), 5'-CGCTTGACGGTCTTGGTTC$3^{\prime}$ and SNR17A and SNR17B (exon 2 primer; U3 snRNA; Myslinski et al. 1990|, 5'-CCAAGTTGGATTCAGTGGCTC-3'. The sizes of the extension products for the pre-mRNA precursors, intermediates, and products are as stated in Madhani and Guthrie (1992). Primer-extension products were separated on $6 \%-8 \mathrm{M}$ urea polyacrylamide gels, dried, and exposed for autoradiography using X-Omat AR (Kodak) or Biomax MR (Kodak). Quantitation was performed as above.

\section{Acknowledgments}

We thank Rick Collins for many discussions concerning this project as well as his helpful comments and suggestions on this manuscript. We also thank Jim Hu for some of the U6 constructs and for helpful discussions. We also thank members of the Friesen and Collins laboratories for comments on this work. We thank Tina Harrington for technical assistance in the early part of this project. This work was supported by grants from the Medical Research Council and the National Cancer Institute of Canada.

The publication costs of this article were defrayed in part by payment of page charges. This article must therefore be hereby marked "advertisement" in accordance with 18 USC section 1734 solely to indicate this fact.

\section{References}

Abovich, N., X. C. Liao, and M. Rosbash. 1994. The yeast MUD2 protein: An interaction with PRP11 defines a bridge between committment complexes and U2 snRNP addition. Genes \& Dev. 8: 843-854.

Ares M., Jr. 1986. U2 RNA from yeast is unexpectantly large and contains homology to vertebrate U4, U5, and U6 small nuclear RNAs. Cell 47: 49-59.

Ares M., Jr., and A.H. Igel. 1990. Lethal and temperature-sensitive mutations and their suppressors identify an essential structural element in U2 small nuclear RNA. Genes \& Dev. 4: 2132-2145.

Bachl, J. and C. Schmelzer. 1990. Effect of deletions at structural domains of group II intron bIl on self-splicing in vitro. J. Mol. Biol. 212: 113-125.

Blanton, S., A. Srinivasan, and B.C. Rymond. 1992. PRP38 encodes a yeast protein required for pre-mRNA splicing and maintenance of stable U6 small nuclear RNA levels. $\mathrm{Mol}$. Cell. Biol. 12: 3939-3947.

Boeke, J.D., J. Truehart, G. Natsoulis, and J. Fink. 1987. 5-Fluoroorotic acid as a selective agent in yeast molecular genetics. Methods Enzymol. 154: 164-175.

Boulanger, S.C., S.M. Belcher, U. Schmidt, S.D. Dib-Haji, T. Schmidt, and P.S. Perlman. 1995. Studies of point mutants define three essential paired nucleotides in the domain 5 substructure of a group II intron. Mol. Cell. Biol. 15: 44794488.

Brow, D. and C. Guthrie. 1988. Spliceosomal RNA U6 is remarkably conserved from yeast to mammals. Nature 334: 213-218.

Burke, J., J.S. Esherick, W.R. Burfeind, and J.L. King. 1990. A $3^{\prime}$ splice site-binding sequence in the catalytic core of a group 
I intron. Nature 344: 80-82.

Chanfreau, G. and A. Jacquier. 1994. Catalytic site components common to both splicing steps of a group II intron. Science 266: $1383-1387$.

Datta, B., and A. Weiner. 1991. Genetic evidence for base-pairing between U2 and U6 snRNA in mammalian mRNA splicing. Nature 352: 821-824.

- 1993. The phylogenetically invariant ACAGAGA and AGC sequences of U6 small nuclear RNA are more tolerant of mutation in human cells than in Saccharomyces cerevisiae. Mol. Cell. Biol. 13: 5377-5382.

Fabrizio, P., D.S. McPheeters, and J. Abelson. 1989. In vitro assembly of yeast U6 snRNP; a functional assay. Genes \& Dev. 3: 2137-2150.

Fortner, D.M., R.G. Troy, and D.M. Brow. 1994. A stem/loop in U6 RNA defines a conformational switch required for premRNA splicing. Genes \& Dev. 8: 221-233.

Fouser, L. and J.D. Friesen. 1986. Mutations in a yeast intron demonstrate the importance of specific conserved nucleotides for the two stages of nuclear pre-mRNA splicing. Cell 45: 81-93.

Frank, D. and C. Guthrie. 1992. An essential splicing factor, SLU7, mediates 3' splice site choice in yeast. Genes \& Dev. 6: 2112-2124.

Galisson, F. and P. Legrain. 1993. The biochemical defects of prp4-1 and prp6-1 yeast splicing mutants reveal that the PRP6 protein is required for the accumulation of the [U4/ U6.U5] tri-snRNP. Nucleic Acids Res. 21: 1555-1562.

Guthrie C. 1991. Messenger RNA splicing in Yeast: Clues to why the spliceosome is a ribonucleoprotein. Science 253: $157-163$

Hausner, T.-P., L.M. Giglio, and A.M. Weiner. 1990. Evidence for base-pairing between mammalian $\mathrm{U} 2$ and $\mathrm{U} 6$ small nuclear ribonuclearprotein particles. Genes \& Dev. 4: 21462156.

Hill, J., K.A.G. Donald, and D.E. Griffiths. 1991. DMSO-enhanced whole cell yeast transformation. Nucleic Acids Res. 19: 5791.

Hu, J., K. Schappert, T. Harrington, A. Wang, R. Braga, J. Modridge, and J.D. Friesen. 1994. Mutational analysis of the PRP4 protein of Saccharomyces cerevisiae suggests domain structure and snRNP interactions. Nucleic Acids Res. 22: 1724-1734

Hu, J., D. Xu, K. Schappert, Y. Xu, and J.D. Friesen. 1995. Mutational analysis of Saccharomyces cerevisiae U4 snRNA identifies functionally important domains. Mol. Cell. Biol. 15: 1274-1285.

Igel A.H. and M. Ares Jr. 1988. Internal sequences that distinguish yeast from metozoan U2 snRNA are unnecessary for pre-mRNA splicing. Nature. 334: 450-453.

Ito, H., Y. Fukada, K. Murat, and A. Kimura. 1983. Transformation of intact yeast cells treated with alkali cations. I. Bacteriol. 153: 163-168.

Jarrell, K.A., R.C. Dietrich, and P.S. Perlman. 1988. Group II intron domain facilitates a trans-splicing reaction. Mol. Cell. Biol. 8: 2361-2366.

Keller, E. and W. Noon. 1985. Intron splicing : a conserved internal signal in introns of Drosophila pre-mRNAs. Nucleic Acids Res. 13: 4971-4981.

Koch, J. L., S.C. Boulanger, S.D. Dib-Haij, S.K. Hebbar, and P.S. Perlman. 1992. Group II introns deleted for multiple substructures retain self-splicing activity. Mol. Cell. Biol. 12: $1950-1958$.

Kunkel, T.A., J.D. Roberts, R.A. Zakour. 1987. Rapid and efficient site-specific mutagenesis without phenotypic selec- tion. Methods in Enzymol. 154: 367-383

Legrain, P. and M. Roshbash. 1989. Some cis- and trans-acting mutants for splicing target pre-mRNA to the cytoplasm. Cell 57: 573-583.

Lesser, C.F. and C. Guthrie. 1993. Mutational analysis of premRNA splicing in Saccharomyces cerevisiae using a sensitive new reporter gene, CUP1. Genetics 133: 851-863.

Liao, X., L. Kretzner, B. Seraphin, and M. Rosbash. 1990. Universally conserved and yeast-specific $U 1$ snRNA sequences are important but not essential for U1 snRNP function. Genes \& Dev. 4: 1766-1774.

Liao, X.C., J. Tang, and M. Rosbash. 1993. An enhancer screen identifies a gene that encodes the yeast U1 snRNP A protein: implications for snRNP protein function in pre-mRNA splicing. Genes \& Dev. 7: 419-428.

Madhani, H.D. and C. Guthrie. 1992. A novel base-pairing interaction between $\mathrm{U} 2$ and U6 snRNAs suggests a mechanism for the catalytic activation of the spliceosome. Cell 71: 803-817.

- 1994a. Randomization-selection analysis of snRNAs in vivo: evidence for a tertiary interaction in the splicesome. Genes \& Dev. 8: 1071-1086.

1994b. Genetic interactions between the yeast RNA helicase homolog Prp16 and spliceosomal snRNAs identify candidate ligands for the Prp16 RNA dependent ATPase. Genetics 137: 677-687.

- 1994c. Dynamic RNA-RNA interactions in the spliceosome. Annu. Rev. Genet. 28: 1-26.

Madhani, H.D., R. Bordonne, and C. Guthrie. 1990. Multiple roles for U6 snRNA in the splicing pathway. Genes \& Dev. 4: 2264-2277.

McPheeters, D.S. and J. Abelson. 1992. Mutational analysis of the yeast snRNA suggests a structural similarity to the catalytic core of group I introns. Cell 71: 819-831

Michel, F., P. Netter, M.-Q. Xu, and D.A. Shub. 1990. Mechanism of 3 ' splice site selection by the catalytic core of the sunY intron of bacteriophage T4: the role of the novel basepairing interaction in group I introns. Genes \& Dev. 4: 777788.

Michels, W.J. and A.M. Pyle. 1995. Conversion of a group II intron into a new multiple-turnover ribozyme that selectively cleaves oligonucleotides: Elucidation of reaction mechanism and structure/function relationships. Biochemistry 34: 2965-2977.

Miraglia, L., S. Seiwert, A.H. Igel, and M. Ares Jr. 1991. Limited functional equivalence of phylogenetic variation in small nuclear RNA: Yeast U2 RNA with altered branchpoint complementarity inhibits splicing and produces a dominant lethal phenotype. Proc. Natl. Acad. Sci. 88: 7061-7065.

Moore, M.J., C.C. Query, and P.A. Sharp. 1993. Splicing of precursors to mRNA by the spliceosome. In The RNA world, Chapter 13, pp. 303-357. Cold Spring Harbor Laboratory Press, Cold Spring Harbor, NY.

Mylinski, E., V. Segault, and C. Branlant. 1990. An intron in the genes for U3 small nucleolar RNAs of the yeast Saccharomyces cerevisiae. Science 247: 1213-1216.

Nilsen, T.W. 1994. RNA-RNA interactions in the spliceosome: Unraveling the ties that bind. Cell 78: 1-4.

Patterson, B. and C. Guthrie. 1987. An essential yeast snRNA with a U5-like domain is required for splicing in vivo. Cell 49: 613-624.

1992. Synthetic lethal mutations suggest interactions between U5 small nuclear RNA and four proteins required for the second step in splicing. Mol. Cell. Biol. 12: $5197-$ 5205 . 
Percival-Smith, A. and J. Segall. 1986. Characterization and mutational analysis of a cluster of three genes expressed preferentially during sporulation. Mol. Cell. Biol. 6: 2443-2451.

Rose, M.D., F. Winston, and P. Hieter. 1990. Methods in yeast genetics: A laboratory manual. Cold Spring Harbor Laboratory Press, Cold Spring Harbor, NY.

Ruby, S.W., T.-H. Chang, and J. Abelson. 1993. Four yeast spliceosomal proteins (PRP5, PRP9, PRP11, and PRP21) interact to promote U2 binding to pre-mRNA. Genes \& Dev. 7: 1909-1925.

Sambrook, J., E.F. Fritsch, and T. Maniatis. 1989. Molecular cloning: A laboratory manual, 2nd ed. Cold Spring Harbor Laboratory Press, Cold Spring Harbor, NY.

Seraphin, B. and M. Roshbash. 1989. Mutational analysis between U1 small nuclear RNA and pre-mRNA splicing in yeast. Gene 82: 145-151.

Shuster, E.O. and C. Guthrie. 1988. Two conserved domains of yeast U2 snRNA are sepearated by 945 nonessential nucleotides. Cell 55: 41-48.

1990. Human U2 snRNA can function in pre-mRNA splicing in yeast. Nature 345: 270-273.

Sikorski, R.S. and P. Hieter. 1989. System of shuttle vectors and yeast host strains designed for efficient manipulation of DNA in Saccharomyces cerevisiae. Genetics 122: 19-27.

Silicano, P.G., W.J. Kivens, and C. Guthrie. 1991. More than half the yeast U1 snRNA is dispensable for growth. Nucleic Acids Res. 19: 6367-6372.

Stutz, F., X.C. Liao, and M. Roshbash. 1993. U1 small nuclear ribonuclear-protein particle interactions are revealed in Saccharomyces cerevisiae by in vivo competition assays. Mol. Cell. Biol. 13: 2126-2133.

Suh, E.R. and R.B. Waring. 1990. Base pairing between the $3^{\prime}$ exon and an internal guide sequence increases $3^{\prime}$ splice site specificity in the Tetrahymena self-splicing rRNA intron. Mol. Cell. Biol. 10: 2960-2965.

Sun, J.-S. and J.L. Manley. 1995. A novel U2-U6 snRNA structure is necesary for mammalian mRNA splicing. Genes \& Dev. 9: 843-854.

Teem, J.L. and M. Rosbash. 1983. Expression of a $\beta$-galactosidase gene containing the ribosomal protein 51 intron is sensitive to the rna2 mutation in yeast. Proc. Natl. Acad. Sci. 80: 4403-4407.

Umen, J.G. and C. Guthrie. 1995. A novel role for a U5 snRNP protein in $3^{\prime}$ splice site selection. Genes \& Dev. 9: 855-868.

Vijayraghavan, U., M. Company, and J. Abelson. 1989. Isolation and characterization of pre-mRNA splicing mutants of Saccharomyces cerevisiae. Genes \& Dev. 3: 1206-1216.

Wassarman, D.A. and J.A. Steitz. 1992. Interactions of small nuclear RNA's with precursor messenger RNA during in vitro splicing. Science 257: 1918-1925.

Watkins, K.P. and N. Agabian. 1991. In vivo UV cross-linking of $U$ snRNAs that participate in trypanosome trans-splicing. Genes \& Dev. 5: 1859-1869.

Weiner, A.M. 1993. mRNA splicing and autocatalytic introns: distant cousins or the products of chemical determinism? Cell 72: 161-164.

Wells, S.E. and M. Ares Jr. 1994. Interactions between highly conserved U2 small nuclear RNA structures and Prp5p, Prp9p, Prp11p, Prp21p Proteins are required to ensure integrity of the U2 small nuclear ribonuclearprotein in Saccharomyces cerevisiae. Mol. Cell. Biol. 14: 6337-6349.

Wolff, T. and A. Bindereif. 1992. Reconstituted mammalian U4/ U6 snRNP complements splicing: a mutational analysis. EMBO I. 11: 345-359.

Wu, J. and J.L. Manley. 1989. Mammalian pre-mRNA branch site selection by U2 snRNP involves base pairing. Genes \& Dev. 3: 1553-1561.

1991. Base pairing between U2 and U6 snRNAs is necessary for splicing of a mammalian pre-mRNA. Nature 352: 818-821.

-1992. Multiple functional domains of human U2 small nuclear RNA: Strengthening conserved stem I can block splicing. Mol. Cell. Biol. 12: 5464-5473.

Yean, S.L. and R.J. Lin. 1991. U4 small nuclear RNA dissociates from a yeast splicesome and does not participate in the subsequent splicing reaction. Mol. Cell. Biol. 11: 5571-5577.

Yu, Y.T., P.A. Maroney, E. Darzynkiewicz, and T.W. Nilsen. 1995. U6 snRNA function in nuclear pre-mRNA splicing: A phosphorothioate interference analysis of the U6 phosphate background. RNA 1: 46-54.

Zhuang, Y. and A.M. Weiner. 1989. A compensatory base change in human U2 snRNA can suppress a branch sitemutation. Genes \& Dev. 3: 1545-1552. 


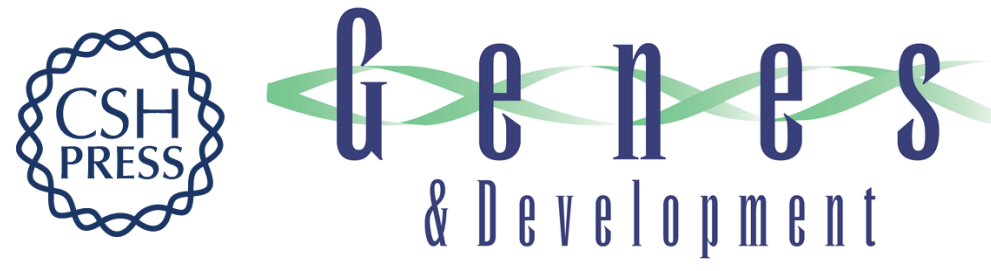

\section{Functionally redundant interactions between U2 and U6 spliceosomal SnRNAs.}

D J Field and J D Friesen

Genes Dev. 1996, 10:

Access the most recent version at doi:10.1101/gad.10.4.489

References This article cites 69 articles, 42 of which can be accessed free at: http://genesdev.cshlp.org/content/10/4/489.full.html\#ref-list-1

License

Email Alerting

Service

Receive free email alerts when new articles cite this article - sign up in the box at the top right corner of the article or click here.

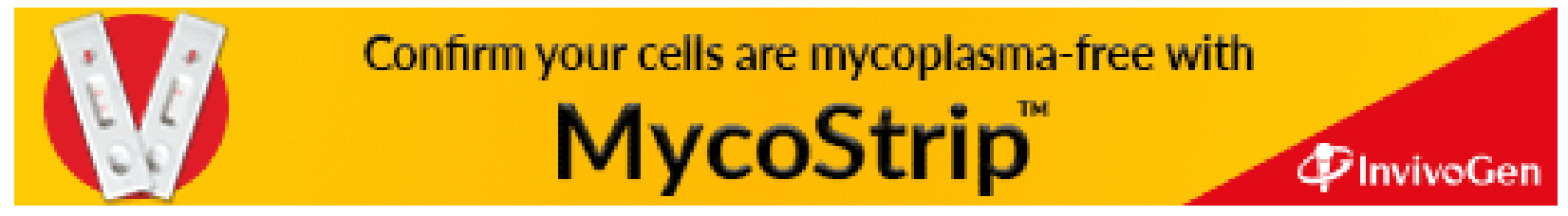

